\section{Humanistyka literaturoznawcza w dobie nowych konfliktów plemiennych. Próba wykonania ruchu}

Ryszard Koziołek
1.

Wypowiedź literaturoznawcza rzadko lub zgoła nigdy nie zajmuje w debacie publicznej pozycji rozstrzygającej. Nie ma dla niej wyraźnego miejsca ani pośród wypowiedzi eksperckich w sporze o prawdziwość przedstawienia (to miejsce głównie dla eksperymentalnych nauk przyrodniczych), ani pośród wypowiedzi performatywnych, które ustanawiają nowy stan rzeczy, nowy "podział zmysłowego"' (tu prymat należy do mediów informacyjnych, sztuki i prawa). Literaturoznawca pociesza się, że jego sądy pracują w dłuższym trwaniu; ich dystrybucja między instytucjami tekstu oraz aplikacja do dyskursu publicznego dokonuje się dłużej, ale za to trwalej osadza się we wspólnocie symbolicznej.

Od dłuższego czasu („początku nie pamiętamy, a końca nie znamy" $^{\prime 2}$ obserwujemy wieloraką, brutalną weryfikację

1 J. Rancière Dzielenie postrzegalnego. Estetyka i polityka, przeł. M. Kropiwnicki, J. Sowa, Korporacja Ha!art, Kraków 2007, s. 69.

2 B. Prus Lalka, oprac. J. Bachórz, BN I 262, Ossolineum, Wrocław 1991, t. 1, s. 31-32.

\section{Ryszard Koziołek}

- literaturoznawca, eseista, nauczyciel akademicki, profesor w Instytucie Nauk o Literaturze Polskiej im. Ireneusza Opackiego Uniwersytetu Śląskiego. W 2010 r. otrzymał Nagrodę Literacką GDYNIA w kategorii eseistyka za książkę pt. Ciała Sienkiewicza. Studia o symbolice płci i przemocy. Ostatnio wydał: Dobrze się myśli literaturą (Wołowiec 2016). Laureat Nagrody im. Kazimierza Wyki (2017). 
tego złudzenia. Humanistyka ponowoczesna afirmowała różnicę pod wieloma postaciami, w obrębie metodologii, pojęć, kultur, ras, języków etc. Akademicka pochwała różnicy i pluralności nie wydostała się jednak w afirmatywnej postaci poza akademię, za to odkrywamy ją poza murami uniwersytetów w wynaturzonej formie różnic odseparowanych, czyli narastających konfliktów politycznych, światopoglądowych, kulturowych, których rosnąca radykalność pozwala mówić o nowych wojnach plemiennych, w rozumieniu, jakie nadał temu terminowi Michel Maffesoli³ . Nie można wykluczyć, że również humanistyka akademicka zajmująca się z taką intensywnością konfliktami symbolicznymi - od mikrofilologii semiotycznej po zderzenia cywilizacji - zaprojektowała model lub była forpocztą wszechogarniającej odmiany dyskursu publicznego, w którym nierozstrzygalny spór jest zasadą komunikacji społecznej. Nie unikając odpowiedzialności, trwam w dobrej wierze przy pytaniu, dlaczego przez niemal cztery dekady dominowania w humanistyce paradygmatu różnicy nie udało się dokonać transmisji tych wartości do społeczeństwa? Dlaczego zawiodła najbardziej podstawowa rola humanistyki, jaką jest tłumaczenie, mediacja, negocjowanie znaczeń?

\section{2.}

Hipoteza, wywiedziona z lektury książki Emily Apter Against World Literature. On The Politics of Untranslatability brzmi, że przyszło nam żyć i pracować w „epoce nieprzetłumaczalności"4 , która wyłoniła się nagle, ku naszemu zdumieniu wprost z wielowiekowej tradycji humanistyki pojmowanej i praktykowanej jako mediacja znaczeń; żmudne, ale ekscytujące wzajemne tłumaczenie się słowników kultur mniejszych i większych, aby w efekcie stworzyć wspólny "dom, w którym, patetycznie mówiąc duch ludzki mieszka" (Kołakowski): „klasycznych pojęć”,,,renesansowego humanizmu”,,,świadomości historycznej”, , literatury światowej”, ,,republiki uczonych" itp. Obietnica dekonstrukcji głosiła, że w obrębie tej umowy humanistycznej można praktykować karnawał różnicy, który jednako nie jest destrukcją i niekończącym się zawieszeniem komunikacji, ale twórczym odsłanianiem genealogicznego rewersu humanistyki uniwersalnej, o którym starała się ona zapomnieć. Ważniejsza

3 M. Maffesoli Czas plemion. Schyłek indywidualizmu w społeczeństwach ponowoczesnych, przeł. M. Bucholc, PWN, Warszawa 2008 (rozdz. Trybalizm).

4 E. Apter Against World Literature. On The Politics of Untranslatability, Verso, New York 2013, s. 8. 
dziś wydaje mi się narastająca świadomość, że mimo radykalnego pluralizmu metodologicznego humanistyki literaturoznawczej wcale nie uprawialiśmy negocjacyjnej komparatystyki odrębnych znaczeń kulturowych, ale mniej lub bardziej wulgarne „tłumaczenie na angielski” (grekę, łacinę, francuski), czyli zajmowaliśmy się zawsze eurodominującą problematyką.

Literaturoznawstwo języków mniejszych popychane intensywnie do włączenia się w system nauki globalnej wyraźnie obnaża porażkę nowoczesnego projektu emancypacji różnicy, który okazuje się projektem totalizującym nie tylko w odniesieniu do integrystycznej fazy wczesnomodernistycznej, ale także w jego okresie radykalnie krytycznym, jakim była dekonstrukcja. Zimny ton Derridy z wielkiego studium o dramacie ,jednojęzyczności” warto czytać bez zwracania uwagi na subtelność i autoironię doskonale zasymilowanego Magrebijczyka, który obscenicznie wyznaje:

nabawiłem się, przyznaję, skrywanej, lecz nieprzejednanej nietolerancji: znoszę lub podziwiam - przynajmniej jeśli chodzi o francuski i tylko w dziedzinie języka - jedynie francuszczyznę czystą. ${ }^{5}$

Porównajmy to z dwoma wczesnonowoczesnymi fragmentami z Sienkiewicza. Pierwszy pochodzi z felietonu z „Gazety Polskiej” z 1875 roku, w którym autor Trylogii zamieścił odpowiedź na list jedenastoletniego Dawidka. Chłopak napisał do gazety w proteście przeciw wykpiwaniu przez Sienkiewicza polszczyzny Żydów. Ten zaś w odpowiedzi pocieszał go:

Gdy nauczysz się czytać i poprawnie mówić i pisać po polsku, wówczas będziesz taki dobry jak i każdy inny, wówczas [...] nikt nie będzie na ciebie napadał i każdy wyciągnie do cię rękę, bez względu na twe pochodzenie i wyznanie. ${ }^{6}$

Ten niewinny fragment felietonu emituje grozę, która sączy się ze słów "napadał”, „pochodzenie i wyznanie”, a jej siedliskiem jest „zły” akcent. Czysta polszczyzna jest (Sienkiewiczowską) obietnicą schronienia, wcale nie gościnnego, ale otrzymania swego rodzaju peleryny-niewidki oferowanej żydowskiemu chłopcu, która pozwoli mu zniknąć, aby być wreszcie dobrze

5 J. Derrida /ednojęzyczność innego, czyli proteza oryginalna, przeł. A. Siemek, "Literatura na Świe-

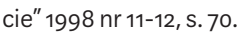

6 H. Sienkiewicz Dzieła XLIX, red. J. Krzyżanowski, PIW, Warszawa 1950, s. 160. 
widzianym. Ideologiczna oczywistość i kulturowa protekcjonalność postawy Sienkiewicza komplikują się, kiedy przystawimy do felietonu fragment noweli $Z$ pamiętnika poznańskiego nauczyciela. Jej bohater, mały Michaś, umiera wycieńczony nieskutecznymi próbami nauczenia się poprawnej wymowy niemieckiej, choć to tylko literacka maska rusyfikacji. „Miałeś zły akcent, ale serce poczciwe" - stwierdza melancholijnie narrator-korepetytor Michasia. Oto finałowa scena pogrzebu chłopca, w którym uczestniczą jego szkolni koledzy:

Oczy dzieci rozszerzały się ze zdziwieniem na widok świec, katafalku i trumny. Może te małe mundurki dziwiła powaga i rola kolegi. Oto niedawno był jeszcze między nimi, zginał się jak i oni pod ciężarem tornistra przeładowanego niemieckimi książkami, dostawał złe stopnie, odbierał połajania i nagany publiczne, miał zły akcent. ${ }^{7}$

Sienkiewicz w ten sposób skomponowany dekonstruuje własny asymilacyjny paternalizm. Oto w cyrkulacyjnej dominacji języków zawsze w końcu mamy „zły akcent”. Humanizm, a później humanistyka zawsze czyniły z języka kryterium korporacyjnej przynależności, obiecując wraz z jego opanowaniem wydobycie się z „barbarzyństwa”. Granicznym punktem była Derridiańska apologia pisma - mowy milczącej - która nie wymaga głośnej artykulacji, a tym samym nie pyta o „pochodzenie i wyznanie”. W ten sposób humanistyka stała się modelem iluzorycznej apologii różnicy, dla której infrastrukturą okazuje się tak naprawdę tylko „jeden” język. Odrzucenie tego modelu zarówno w jego emancypacyjnym kształcie (Sienkiewicz), jak i ekskluzywno-krytycznym (Derrida) prowadzi do zjawisk dotkliwie widocznych w debacie publicznej. Akademicki język pluralizmu i różnicy jest postrzegany jako język eksperckiego korporacjonizmu, któremu nie przypisuje się już rangi metajęzyka, ale sprowadza do roli instrumentu zapewnienia dominacji symbolicznej, którym posługują się także intelektualiści w swoich branżowych walkach.

7 H. Sienkiewicz Z pamiętnika poznańskiego nauczyciela, w: tegoż Wybór nowel i opowiadań, oprac. T. Bujnicki, BN I 231, Ossolineum, Wrocław 1988, s. 194

8 Projekt Krzysztofa Wodiczki Laska tułacza (1992) stanowi performansową interwencję artystyczną potwierdzającą trwałość wykluczającego działania "akcentu” dla kogoś, kto jako uchodźca pojawia się w przestrzeni dominującego języka. Zob. np.: http://artmuseum.pl/pl/ filmoteka/praca/wodiczko-krzysztof-instrumentations (2.02.2017). 
Nie byłoby to może tak niepokojące, gdyby nie fakt, że obserwujemy przejawy powszechnej nieufności wobec wypowiedzi eksperckich, łącznie z tym, że dyskurs społeczny, obywatelski, odwołujący się do idei wspólnoty różnic, został zinterpretowany jako korporacyjny szyfr, który maskuje złe intencje oraz służy porozumiewaniu się elit, natomiast „zwykli ludzie” mówią inaczej, czyli właściwym „wspólnym językiem”, jakim mówi skrzywdzony lud. To coś więcej niż antyintelektualna, populistyczna mowa, to przekonanie, że zamiast procesu doskonalenia się języków lub zdobywania eksperckiej sprawności posługiwania się „jednym” językiem, języki mniejsze także pragną orzekającej lub performatywnej mocy, ale na innej drodze niż doskonałość merytoryczna. Obrastając gniewem mówiących nimi ludzi, znajdą najbardziej uniwersalny język oporu: krzyk i niszczące czyny. Pragnienie jednego (mojego języka) jest zawsze przyzywaniem przemocy i nie jest to wyłącznie problem humanistyki akademickiej, ale powszechna, ciemna energia przenikająca społeczną rzeczywistość. Pisał niedawno Przemysław Czapliński w raporcie Reforma kulturowa $2020-2030-2040$ :

Należy to podkreślić: polska literatura ostatniej dekady, potraktowana jako zapis i prospekt zbiorowych tożsamości, mówi wyraźnie, że nie ma dzisiaj takiej grupy społecznej, która cofałaby się przed stosowaniem przemocy. Narodowcy i homoseksualiści, konserwatyści i pluraliści, prawicowcy i feministki, katolicy i antyfaszyści, obrońcy krzyża i obrońcy zwierząt - wszyscy oni opowiadają o aktach zastosowania siły w odpowiedzi na niesprawiedliwość. ${ }^{9}$

Żadne to pocieszenie, że humanistyka uniwersytecka powiela te same fantazje o przemocy i wobec mnożenia się wynaturzonych, odseparowanych różnic śni o wypowiedzi sprawczej i rozstrzygającej. Nie tylko humanistyka rodzima. W niezwykłej książce, będącej dialogiem epistolarnym między Jeanem Vanier i Julią Kristevą, ten pierwszy pisze o swoim zdumieniu pogardą, jaka w wielojęzycznej Szwajcarii spotyka sąsiedzkie języki:

byłem zaszokowany postawą młodej Szwajcarki z Valais, która mówiła o języku niemieckim, używanym po drugiej stronie tego samego kantonu, jako o języku „barbarzyńskim”. Jak to się dzieje, że w Belgii czy w Kanadzie

9 P. Czapliński, w: Reforma Kulturowa 2020 - 2030 - 2040, 2015, red. J. Żakowski http://nck.pl/obserwatorium-kultury/317212-2015-reforma-kulturowa-2020-2030-2040. 
nie mówi się równocześnie oboma językami narodowymi? Odmowa zrozumienia drugiego, niemożność komunikowania się z nim jest rodzajem odmowy wstąpienia na drogę spotkania i zgody. ${ }^{10}$

Kristeva odpowiada:

Różnice ideologiczne, narodowe, polityczne, religijne, rasowe itp. tworzą przestrzenie władzy albo wykluczenia; dążą do przywłaszczenia sobie czasu, uważają się za depozytariuszy absolutu i w efekcie rozprzestrzeniają śmierć dla myśli i dla życia. Zwalczam je, kiedy dorastają do zabijania. Mogę wybaczyć osobom, które podzielały je, ale oddalają się od nich, jednak nie wybaczam systemom wierzeń wprost lub pośrednio integrystycznych lub śmiercionośnych."

Co to znaczy: nie wybaczać „systemom wierzeń”? Jak wyobraża sobie Kristeva pedagogikę struktur dyskursu ideologicznego - usieciowionych, odpersonalizowanych, autonomicznych, amplifikowanych algorytmami informatycznymi?

\section{3.}

Chciałbym pójść tropem Kristevej i zastanowić się przez chwilę nad pewną możliwością humanistyki literaturoznawczej, która wykonując swoje tradycyjne zadania badawcze i edukacyjne, dokonuje wspomnianego aktu zwalczania różnicy, która „wyklucza i zmierza do zabijania”. Ów akt ujmuję jednak, na zasadzie alegorezy, nie w kostium baśni czy mitu, ale westernu, i to westernu konkretnego. Ekscentryczność tego pomysłu jest pozorna. Westerny są przepełnione dydaktyką polityczną. Ogromna większość odtwarza ten sam scenariusz: kryzysu demokracji i jego przezwyciężenia, i jednocześnie nieustannie wytwarza ponownie mit amerykańskiej modernizacji. Modelowym (i moim zdaniem niedoścignionym) przykładem jest film Johna Forda Człowiek, który zabił Liberty Valancéa! (1962). Przypomnę krótko fabułę.

Miasteczko Shinebowne ma małą społeczność i trzech bohaterów: Ransom Stoddard - adwokat i polityk (James Stewart); Liberty Valance

\footnotetext{
10 J. Kristeva, J. Vanier (Bez)sens słabości. Dialog wiary z niewiarq o wykluczeniu, przeł. K. i P. Wierzchosławscy, Wydawnictwo Polskiej Prowincji Dominikanów W drodze, Poznań 2012, s. 137. 
- bandyta (Lee Marvin) i Tom Doniphon (John Wayne) - rewolwerowiec z zasadami. Narracja jest retrospektywna. Stoddard, polityk sukcesu, opowiada o tym, jak udało się zbudować w Shinebowne nowoczesną demokrację, a jemu samemu zrobić karierę: od prowincjonalnego prawnika do gubernatora, senatora i ambasadora. Przybył właśnie do Shinebowne na pogrzeb Doniphona.

Po raz pierwszy Stoddard trafił do miasta jako młody adwokat, „naiwny pielgrzym demokracji". Napadnięty i pobity przez Valance’a, współorganizuje legalne wybory i sam w nich kandyduje. Liberty stosuje o wiele prostszą perswazję polityczną: - Kto na mnie nie zagłosuje, tego zabiję. Mimo to wybory się udają. Kiedy pijany i wściekły Valance wyzywa na pojedynek Stoddarda, ten właśnie zmywa naczynia, spłacając dług szwedzkiej rodzinie, która pomogła mu dojść do zdrowia. Tym razem nie wytrzymuje i wychodzi na ulicę w śmiesznym fartuchu, bez pasa i kapelusza, z pistoletem niezdarnie trzymanym w ręce. Liberty rani go i upokarza, Stoddard upada na kolana, ale ostatnim desperackim ruchem podnosi pistolet i strzela do Valance'a. Zło zostaje pokonane i odtąd miasto rozwija się wspaniale, podobnie jak kariera Stoddarda. Teraz, po latach, poznajemy inną wersję wydarzeń. Okazuje się, że skryty w bocznej uliczce Tom strzelił z karabinu, ratując demokratę przed bandyta. Stoddard długo był przekonany, że jest zabójcą. Dopiero, kiedy z powodu wyrzutów sumienia chciał się wycofać z kandydowania do władz stanowych, Tom powiedział mu, kim naprawdę jest człowiek, który zabił Liberty Valance'a. Nikt się o tym nie dowiedział za życia Doniphona, podobnie, jak nie wiedziano o ich przyjaźni.

\section{4 .}

Adaptuję tę scenę jako alegorię interwencji literatury w pole publicznej debaty, modyfikując jej główny składnik, tj. eliminację antagonisty. Poprzestaję na zaaranżowaniu interwencji krytycznej, która umożliwia, że obraz poetycki lub sekwencja narracyjna dokonuje interwencji w dziejącą się, choć pogrążoną w impasie, debatę publiczną. Interwencja musi dysponować środkami transmisji kulturowej, które umożliwią i wzmocnią przemoc symboliczną wypowiedzi literaturoznawczej, ale jej funkcja jest inna niż w przypadku westernowego strzału zza węgła. Działa ona raczej wedle strategii „kukułczego jaja" - podrzucona w pole debaty, skąd zostaje podjęta przez uczestników konfliktu. Westernowa inscenizacja kryzysu demokratycznego dialogu zwraca uwagę na sekretność tego procederu, który dokonuje się z ciemnego 
zaułka i bez identyfikacji osoby sprawcy. Wobec kryzysu autorytetów eksperckich i podstawowej nieufności wobec aktorów publicznej debaty nie sposób dziś zajmować uprzywilejowanej pozycji krytycznej, co z kolei rodzi pułapkę utajonego uwikłania we wspieranie jednej ze stron konfliktu. W modelu westernowym interwencja dokonuje się „ze środka”, co odpowiada przekonaniu, że sztuka krytyczna lub krytyka krytyczna nie mogą zająć pozycji zewnętrznej (neutralnej, niezależnej, czysto eksperckiej, zrywającej z porządkiem, który krytykuje itp.). Pisze o tej pozycji interwencyjnej Chantal Mouffe, nazywając autorów takich praktyk - za Gramscim - „intelektualistami organicznymi”:

Konstruując nowe praktyki i nowe podmiotowości, mogą pomóc w podważeniu istniejącej konfiguracji władzy. Zawsze była to rola artystów i tylko modernistyczna iluzja uprzywilejowanej pozycji sztuki sprawiła, że możliwe stało się przyjęcie innego poglądu. ${ }^{12}$

Uprzedzam drwinę w retorycznym pytaniu: czy nowa interpretacja chochoła z Wesela może wpłynąć w jakikolwiek sposób na spór rządu z opozycją? Tak, właśnie o takiej interwencji prowadzi się tu fantazjujący wywód. Interwencja literaturoznawcza byłaby szansą osłabienia antagonistycznego modelu debaty, wyhamowania jej niszczącego impetu, za sprawą reorganizacji wektorów konfliktu. Pod warunkiem, że literaturoznawca umożliwi interwencję literatury w polu debaty publicznej, organizowanej coraz częściej przez antagonistyczną, gniewną nienawiść'13. Celem interwencji byłaby reorientacja czy choćby dezorientacja takiego konfliktu. Potencjał dywersyfikacyjny literatury jest w tym względzie niedościgniony, szczególnie kiedy używamy do tego tekstów klasycznych, uznawanych za emblematyczne dla kultury dominującej, jakimi są w Polsce Pan Tadeusz czy Trylogia.

\section{5.}

Pole eksperymentu jest nieskończone. Spośród najboleśniejszej odmiany konfliktu, jakim jest wojna domowa, można symbolicznie wyodrębnić cztery

12 Ch. Mouffe Agonistyka. Polityczne myślenie o świecie, przeł. B. Szelewa, Wydawnictwo Krytyki Politycznej, Warszawa 2015, s. 110.

13 Przykładem fortunnych interwencji są np.: zdanie Jarosława Marka Rymkiewicza o Jarosławie Kaczyńskim, który ugryzł Polskę-żubra w dupę; teza Andrzeja Ledera o prześnionej rewolucji czy Jana Sowy o folwarcznej mentalności współczesnej klasy średniej. 
akty krwawej nienawiści wewnętrznej, do jakich doszło w Rzeczypospolitej w ciągu czterech stuleci, oraz znaczące, artystyczne odpowiedzi na te wydarzenia: powstanie Chmielnickiego (Ogniem i mieczem); rzeź Humania (Zamek kaniowski); Rabacja Galicyjska (Wesele); rzeź wołyńska (Zasypie wszystko, zawieje). Literatura, zwłaszcza epika historyczno-przygodowa, magazynuje zapisy gniewu i przemocy, dzięki swoistej nieodpowiedzialności sztuki; pewnej sztuki, która odtwarza i eskaluje historyczną nienawiść dla korzyści dramaturgicznych. W przeciwieństwie do podobnych praktyk w polityce, literatura może „rozwiązać” krwawy konflikt ładem konwencji, a nie przywróceniem ładu społecznego. Literaturoznawca ma szansę przywrócić dyskurs racji, zatrzymując konflikt w nierozstrzygalnej pozycji, w analitycznej stop-klatce, unieruchamiając „aktorów” w pozycji, w której konflikt zastyga w absolutnej nieprzetłumaczalności, ale nie może też wyładować się w akcie przemocy.Ten rodzaj odseparowanej, czystej różnicy, która w przestrzeni publicznej objawia się nam jako niebezpieczna i niszcząca, różni się od różnicy akademickiej otuliną gniewnego lub nienawistnego afektu. Nienawistny konflikt, niedopuszczalny w przestrzeni debaty akademickiej, może zostać przez literaturoznawcę zinterioryzowany w obręb krytyki akademickiej, która nada mu na powrót formę konfliktu racji, a nie wyłącznie gniewu i nienawiści.

Tak przeczytana klasyczna polska literatura opowiadająca o nierozwiązywalnych konfliktach społecznych Ogniem i mieczem, nie jest już książką integrystyczną, „dla Polaków”, ale sceną, na której wyszły na jaw nasze fantazmatyczne popędy. To dobra droga do innej wspólnoty z „innymi”, zbudowana na podobieństwie różnic, które wydobyła z nas literatura, demaskując naszą nieprzyległość do własnych wyobrażeń o sobie. Ten proces odróżniania się od siebie samego tak opisuje Slawoj Žižek:

A co będzie, jeśli poznawanie ich ujawni nam, że są - mniej lub bardziej - tacy, jak my: niecierpliwi, gwałtowni, roszczeniowi, a w dodatku zwykle reprezentują kultury, które nie uznają wielu wartości, traktowanych przez nas jako oczywiste? Dlatego należy przeciąć ten rodzaj sprzężenia, jaki zachodzi między uchodźcami a humanitarną empatią, wskutek którego naszą pomoc dla nich opieramy na współczuciu dla ich cierpień. Powinniśmy raczej pomagać im, bo naszym obowiązkiem etycznym jest to czynić, ponieważ nie możemy im nie pomagać, jeśli chcemy pozostać przyzwoitymi ludźmi, jednak bez tego sentymentalizmu, który przestaje działać w chwili, kiedy zdajemy sobie sprawę, że większość uchodźców, 
to nie są "ludzie tacy, jak my” (nie dlatego, że są cudzoziemcami, ale dlatego, że my sami nie jesteśmy „ludźmi takimi, jak my”.14

Ten rodzaj pracy literaturą pozbawia ją funkcji odróżniania "nas” od „nich”, ale uczy odróżniania "nas" od „nas", ćwicząc w ten sposób trudną umiejętność życia z sobą jako „innym” od własnych wyobrażeń.

\section{Abstract}

\section{Ryszard Koziołek}

UNIVERSITY OF SZCZECIN

Literary Studies in the Era of New Tribal Conflicts: Trying to Make a Move

The postmodern humanities have affirmed difference in the fields of methodology, concepts, cultures, races, languages, etc., and yet the celebration of difference and plurality has not spread beyond the academe - at least not in an affirmative manner. Instead, this celebration of difference takes on the distorted form of separate differences, increasing cultural clashes and new tribal conflicts. This results in agonistic attitudes, which reinforce the notion that 'the public space is the battleground where different hegemonic projects are confronted, without any possibility of final reconciliation' (Chantal Mouffe). Koziołek explores how literary studies can fulfil their traditional tasks of research and education while also performing an act of combating difference, which, according to Kristeva, excludes and tends to kill.

\section{Keywords}

difference, separation, tribal conflict, intervention

14 S. Žižek The Limits of Neighbourhood, w: tegoż Against the Double Blackmail. Refugees, Terror and Other Troubles with our Neighbours, Allen Lane, London 2016, s. 81-82. 